\title{
Perang Tagar Di Ruang Virtual Diskursus Politik Capres Pasca Debat Putaran Kedua
}

\author{
Ana Fitriana P, Ema, Fardiah Oktariani Lubis \\ Program Studi S1 Ilmu Komunikasi, Fisip Unsika, Jl. HS. Ronggowaluyo Telukjambe, Karawang \\ ana.fitriana@fisip.unsika.ac.id,ema@fisip.unsika.ac.id, fardiah.lubis@ fisip.unsika.ac.id \\ Masuk tanggal : 19-09-2019, revisi tanggal : 24-02-2020, diterima untuk diterbitkan tanggal : 25-02-2020
}

\begin{abstract}
This study aims to uncover the political discourse of the Presidential Candidates after the second round of debates, Jokowi VS Prabowo in virtual space. The background of the political discourse of the 2019 Presidential Election debate in the virtual space gave rise to various responses and sentiments among the supporters. After the Presidential Election debate, the hashtag war between \#BohongLagiJokowi and \# 02GagapUnicorn on social media Twitter became the main discussion. The aim is to disperse the power, ideology, and interests behind the presidential political discourse through the Fairclough Critical Discourse Analysis. The research method uses qualitative methods to parse the problem in research, using critical thinking as a basis for research. The results showed the tweet of Prabowo supporters trying to show stunts through language. The use of subject pronouns such as the word Mukidi to dwarf the subject, also uses the hashtags \#DeletJokowi, \#UnistallJokowi, and \#BohongLagiJokowi as symbols of virtual communication. In contrast, the tweet of Jokowi's supporters sent a stuttering sentiment because they didn't understand the e-comer business. Hashtag \# 02GagapUnicorn as a virtual symbol for organizing texts. In the order of messo or the production of text, the two supporters make a virtual symbol through the hashtag to become a topic of discussion on Twitter. In the situational or macro aspects are influenced by the post-truth phenomenon that is vague information whose source is unclear, have an impact on the inclusion of opinions on the assassination of certain characters. The advice, wise social media, understand and thoroughly source of information, is not affected by the use of certain metaphors, and at the stage of text, production needs to pay attention to the effects that will impact on the influence of social psychology of each supporter.
\end{abstract}

Keywords: discourse, hashtag, virtual space, war politics

\begin{abstract}
Abstrak
Penelitian ini bertujuan untuk mengungkap diskursus politik Capres pasca debat putaran kedua, Jokowi VS Prabowo di ruang virtual. Dilatarbelakangi oleh lanskap diskursus politik debat Pilpres 2019 di ruang virtual yang menimbulkan berbagai tanggapan dan sentimen di antara kedua kubu pendukung. Pasca debat Pilpres perang tagar antara \#BohongLagiJokowi dan \#02GagapUnicorn di Twitter menjadi pembahasan utama. Tujuannya untuk membongkar kuasa, ideologi dan kepentingan di balik wacana politik Pilpres melalui analisis wacana kritis Fairclough. Metode penelitian menggunakan metode kualitatif untuk mengurai masalah dalam penelitian, dengan menggunakan pemikiran kritis sebagai dasar pijakan penelitian. Hasil penelitian menunjukan tweet warganet pendukung Prabowo berusaha menunjukkan pengkerdilan melalui Bahasa. Penggunaan kata ganti subjek seperti kata Mukidi untuk mengkerdilkan subjek, juga menggunakan
\end{abstract}


tagar \#DeletJokowi, \#UninstallJokowi dan \#BohongLagiJokowi sebagai simbol komunikasi virtual. Namun sebaliknya, tweet warganet pendukung Jokowi membuat sentimen dengan kata-kata gagap karena tidak memahami bisnis milenial (e-commerce). Tagar \#02GagapUnicorn sebagai simbol virtual untuk pengorganisasin teks, sedangkan di tahapan produksi teks (messo) kedua pendukung membuat simbol virtual melalui tagar (\#) untuk menjadi tren topik pembahasan di Twitter. Pada aspek situasional (makro) dipengaruhi oleh fenomena post-truth yaitu informasi-informasi samar yang tidak jelas sumbernya, berdampak terhadap penggiringan opini terhadap pembunuhan karakter tertentu. Sarannya, bijak bermedia sosial, pahami dan teliti sumber informasinya, tidak terpengaruh terhadap penggunaaan metafora tertentu, serta pada tahap produksi teks perlu memperhatikan efeknya yang akan berdampak pada pengaruh psikologi sosial masingmasing pendukung.

Kata Kunci: diskursus, politik, perang tagar, ruang virtual

\section{Pendahuluan}

Diskursus politik pasca debat Capres antara Jokowi VS Prabowo pada Minggu malam 17 Februari 2019 di Hotel Sultan, menjadi perdebatan di antara kedua pendukung di ruang virtual. Tema yang diusung tentang energi, pangan, sumber daya alam, lingkungan hidup, dan infrastruktur, menimbulkan perdebatan di kalangan pendukung fanatik masing-masing kandidat. Pasalnya, komunikasi politik kedua kandidat dinilai kompleks preferens dalam menyajikan data. Terlebih kandidat nomor urut 01 Jokowi banyak mengurai data-data yang tidak sesuai.

Dikutip dari salah satu akun TwitterVIVAAcoid@VIVVAcoid pada tanggal 18 Februari 2019, melalui unggahan-nya "Pasca Debat Pilpres 2019 putaran kedua yang berlangsung tadi malam, 17 Februari 2019, Twitter riuh dengan tagar \#JokowiBohongLagi dan \#02GagapUni-corn." Tagar \#JokowiBohongLagi merupakan reaksi warganet atas ketidaksesuaian data saat pemaparan capaian pembangunan ketika masa jabatannnya. Sementara, tagar \#02GagapUnicorn ditujukkan kepada Capres nomor urut 02 Prabowo Subianto, saat debat mengalami gagap mengenai pembahasan e-commerce atau Unicorn.

Alhasil, tweet warganet di media Twitter di dominasi oleh sentimen negatif dari penampilan kedua kandidat. Hingga berakhirnya debat pukul 22.00 WIB, berdasarkan data Analisis Sentimen Twitter (Haddiyat, 2019), sentimen negatif Jokowi-Ma'ruf mencapai 39\%, sedangkan Prabowo-Sandi sentimen negatif mencapai $21 \%$ pada penutupan. Berikut data analisis setimen twitter pada Grafik.1 dan 2;

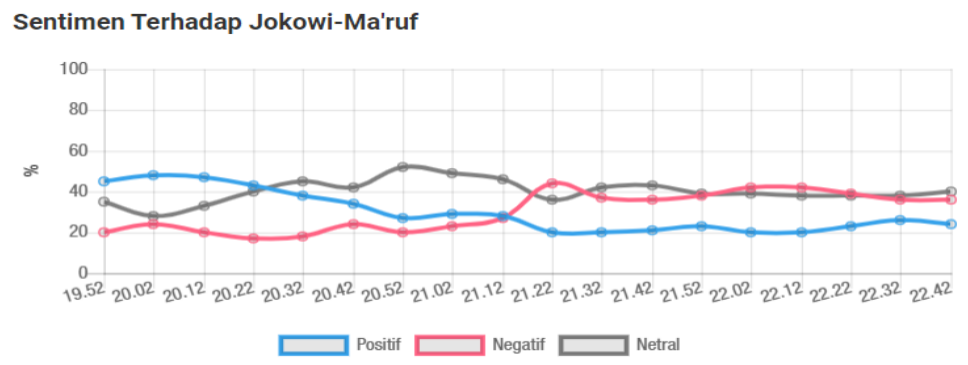

Grafik 1: Analisis Sentimen Twitter Prabowo-Sandi (Sumber: Haddiyat, 2019) 


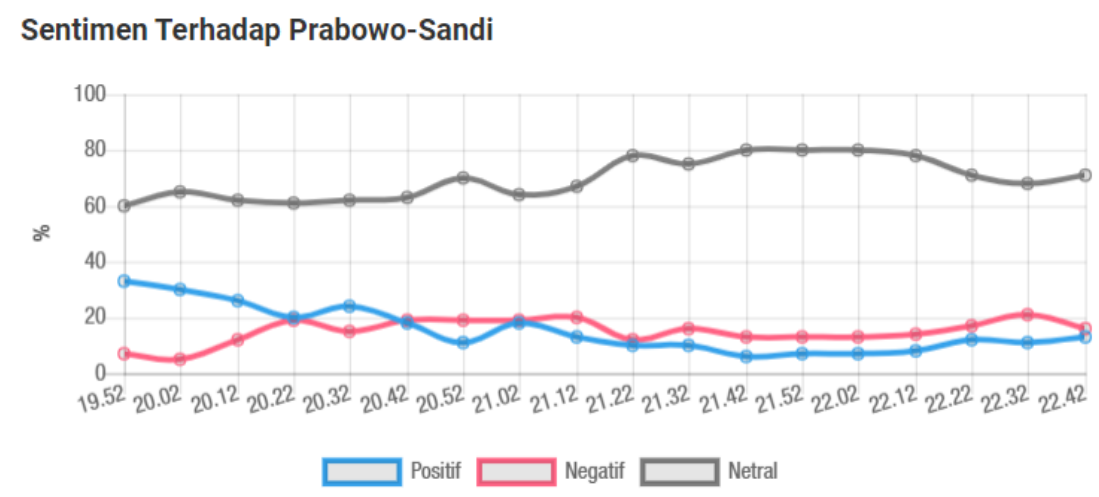

Grafik 2: Analisis Sentimen Twitter Jokowi- Ma'ruf (Haddiyat, 2019)

Data analisis sentimen Twitter Jokowi-Ma'ruf mendapat respon positif yang lebih besar dari warganet di berbagai media sosial dibandingkan dengan lawannya Prabowo-Sandiaga. Hasil analisis berdasarkan data 53,39\% warganet menuliskan Jokowi. Adapun rifalnya Prabowo diunggahan warganet sebesar 46,61\%. Ada dua tagar utama yang menjadi perbincangan warganet, yakni \#Bohong-LagiJokowi dan \#02-GagapUnicorn.

Keramaian yang terjadi di ruang virtual tidak terlepas dari reaksi kedua pendukung Capres ketika menanggapi hasil debat. Pernyataan Jokowi, "ketika menjabat tidak terjadi lagi kebakaran hutan dan gambut." Ramai reaksi tweet warganet pendukung 02 dengan unggahan bernada negatif tersebut, yang terjadi menurut data yang ada hingga kini kebakaran hutan dan lahan gambut masih berlangsung. Beberapa daerah seperti di Kalimantan dan Riau masih sulit untuk ditanggulangi. Selain itu, pernyataan lainnya Jokowi yaitu, "selama menjabat tidak ada konflik pembebasan lahan, tidak ada ganti rugi yang ada ganti untung." Dari laporan pemberitaan media online Kompas.com (Ayu, 2019), terjadi konflik akibat pembangunan infrastruktur PLTU di Batang, Jawa Timur. Konflik penggusuran secara paksa, sekitar 90 kasus atau sekitar 30\% terjadi akibat pembangunan property, dan 94 kasus sektor pembangunan infrastruktur.

Lebih mendalam, hadirnya sentimen melalui tagar \#02GagapUnicorn muncul ketika sesi tanya jawab tentang ekonomi digital (Unicorn). Jokowi ketika itu mempertanyakan kepada Prabowo, terkait "Infrastruktur apa yang akan Bapak bangun untuk mendukung pengembangan Unicorn-Unicorn di Indonesia?" Prabowo, "Yang bapak maksud Unicorn? Unicorn? Yang apa itu online-online itu?" Hal ini yang mengundang sentimen warganet dari kubu 01 seperti, @SiswantiYeni, "Gara-gara Wowo cengok soal Unicorn pada debat pilpres, kata "Unicorn" jadi trending topic dimari. Sebenernya kalian tau gak sih apa itu Unicorn, yuk simak bareng-bareng, gaes supaya gak kaya Wowo yang tahunya cuman "onlen-onlen"\#02GagapUnicorn. \#Unicorn." Sentimen tersebut ditulis oleh warganet pendukung Jokowi-Ma'ruf sebagai ungkapan untuk mengolok-olok warganet pendukung Prabowo-Sandiaga.

Kontestasi politik antara Jokowi VS Prabowo di Pilpres 2019 berlanjut ke debat-debat selanjutnya. Istilah sebutan "Cebong" bagi kubu warganet pendukung Jokowi-Maruf, sedangkan istilah "Kampret" sebutan bagi pendukung warganet 
pendukung Prabowo-Sandiaga. Kedua kubu ramai memberikan pernyataan politiknya terhadap masing-masing dukungannya sesuai dengan perkembangan isu politik yang berkembang. Usai debat masing-masing kubu, seperti yang disampaikan oleh Tim Kampanye Nasional (TKN) Jokowi-Ma'ruf dan Badan Pemenangan Nasional (BPN) Prabowo-Sandiaga, mengklaim menang debat.

Perang tagar di media virtual tidak terlepas dari komunikasi politik kandidat Capres pada Pilpres tahun 2019. Aktor politik dan buzzer ikut meramaikan hiruk pikuk perpolitikan di ruang media sosial. Setiap isu yang akan melemahkan kandidat Capres, menjadi perdebatan antara kedu pendukung. Tak ayal pertarungan wacana politik dalam diskursus elektoral, menjadi pergulatan dalam meraih kemenangan dalam pemilu.

Untuk itu, gaya komunikasi politik masing-masing kandidat menjadi ruang kritik dan penafsiran di ruang virtual, yang akhirnya, perang tagar \#JokowiBohongLagi dan \#02GagapUnicorn dapat diinterpretasi di media Twitter menjadikan kajian menarik untuk dibahas. Bagaimana diskursus politik warganet pendukung Capres dimaknai pada level interteks (mikro)? Seperti apa interrelasi teks (messo), dari materi debat hingga menjadi trending topik di media Twitter? Tak ada teks yang berdiri sendiri, melainkan dibentuk oleh pengaruh sosial-budaya dan kontek (makro) yang melatarbelakanginya.

Komunikasi dilihat dari Bahasa "communicateus" atau "communicare" yang mengandung arti berbagi atau milik bersama (Riswandi, 2009). Komunikasi sebagai media untuk berinteraksi, untuk bertukar informasi dan berbagi untuk mendapatkan respon. Saling berbagi informasi, gagasan, atau sikap, berbagi perilaku atau sikap hidup melalui perangkat kepercayaan dan nilai-nilai yang dianut. Sebagai upaya untuk menyampaikan sikap dan tujuan kepada orang lain agar mau mengubah sikap, pendapat dan perilaku baik langsung maupun tidak langsung (Sahreza, 2018).

Suatu langkah yang efektif untuk menguraikan suatu tindakan komunikasi melalui pertanyaan, "Siapa yang berbicara, hal apa yang dibicarakan, dengan menggunakan media apa, kepada siapa lalu apa efeknya' (Cangara, 2010). Dari pernyataan tersebut bisa dipahami arti komunikasi dari setiap aspek kehidupan.

Komunikasi merupakan sebuah proses penyampaian pengetahuan atau pesan melalui sistem alam yang ada di bumi ini. Komunikasi yang dilihat dari hasil interaksi manusia melalui makhluk yang ada di semesta ini. Ada sebuah kebutuhan antar individu untuk melakukan tindakan komunikasi yang berkaitan dengan kepentingan dan hajat seseorang. Tanpa berkomunikasi tentu akan sulit merealisasikan tujuannya tersebut, sehingga menjadi hal yang menarik bahwa komunikasi menjadi alat untuk pemenuhan kebutuhan manusia.

Di era sekarang ini muncul dan berkembangnya internet membawa cara komunikasi baru di masyarakat. Media sosial hadir dan merubah paradigma berkomunikasi di masyarakat saat ini. Komunikasi tak terbatas jarak, waktu, ruang. Bisa terjadi di mana saja, kapan saja, tanpa harus tatap muka. Bahkan media sosial mampu meniadakan status sosial, yang sering kali sebagai penghambat komunikasi. Hadirnya platform media sosial dan sejenisnya, orang-orang tanpa harus bertemu, bisa saling berinteraksi. Jarak tak lagi menjadi masalah dalam berkomunikasi. Lama waktu terakhir bertemu pun juga tak lagi menjadi masalah dan karena 
Ana Fitriana P, Ema, Fardiah Oktariani Lubis: Perang Tagar Di Ruang Virtual Diskursus Politik Capres Pasca Debat Putaran Kedua

kemudahan penggunaannya, hampir bisa dikatakan, siapa saja bisa mengakses dan memanfaatkan media sosial. (Watie, 2011).

Media sosial merupakan salah satu pengembanagan media komunikasi melalui jejaring internet. Internet atau interconnected network, berdampak pada perubahan gaya berkomunikasi. Internet menjadi sebuah medium penyampaian pesan yang begitu cepat. Di antara salah satu contoh platform media sosial yang sering digunakan adalah; Facebook, Instagram, Twitter, dll. (Anastasia \& Emertus, 2014).

Pembahasan tentang politik selalu identik dengan tujuan kekuasaan. Sudah menjadi sifat dasar manusia untuk memilih jalan kekuasaan untuk kepentingannya, dengan kekuasaan, setiap orang memiliki potensi dan kretivitas dalam implementasi citra positif maupun negatif. Dalam dunia politik sarana atau media merupakan sebuah keharusan bagi seorang aktor politik. Adanya saluran politik, maka kinerja-kinerja politiknya akan mudah terkomunikasikan dengan tepat dan efesien.

Saluran politik merupakan sarana yang selalu digunakan untuk menyampaikan pesan-pesan politik kepada khalayak sasaran. Pesan-pesan politik yang dimaksud dalam konteks di sisni yaitu konten-konten, atau simbol-simbol dalam bentuk teks, gambar, visual, mupun program. Dapat pula dengan melakukan kombinasi lambang hingga menghasilkan cerita, foto, termasuk pula pementasan drama. Alat yang dimaksud di sini tidak hanya berbicara sebatas pada media mekanis, teknik, dan sarana untuk saling bertukar lambang, namun manusia pun sesungguhnya bisa dijadikan sebagai saluran komunikasi. (Siagian, 2015).

Di dunia perpolitikan, penggunaan media sosial sebagai senjata utama untuk mendiseminasikan kepentingan politik tertentu. Bagaimana media sosial telah mengubah lanskap politik, dari urusan yang sederhana hingga urusan yang rumit dan kompleks. Pada intinya media sosial memiliki tempat di hati masyarakat untuk berkomunikasi langsung dengan pemilihnya. Media tersebut sangat memudahkan proses politik menjadi lebih murah dan tidak membebankan biaya iklan serta popularitasnya. Seorang aktor politik akan lebih mudah untuk menggalang jaringan dan dan kampanye melalui relawan-relawan sosial dan yang paling penting yaitu bagaimana pengaruh media sosial dapat menggiring dan merubah opini publik melalui pencitraan, bahkan mampu merubah peta persaingan dan konflik antar pendukung, karena begitu kuatnya pengaruh media sosial.

Akan tetapi, dari sekelumit problematikan yang ada dalam lanskap perpolitikan, yaitu pengaruh media sosial menjadi kekuatan untuk membalas lawan politik melalui pengkaburan informasi. Setiap pendukung memiliki kekuatan untuk pembenaran-pembenaran yang berdasarkan logika masing-masing. Dimana kondisi tersebut dinamakan dengan istilah post-truth, yaitu media sosial sebagai alat untuk menyebarkan berita yang seolah-olah benar. Banyak politisi-politisi yang berhasil memenangkan kontestasi politik elektoralnya menggunakan media sosial sebagai senjata utamanya. Meskipun beberapa informasi banyak yang tidak valid dan tidak berdasarkan data yang tepat. Hal ini terjadi diberbagai negara.

Untuk fokus dalam kajian komunikasi politik yang merupakan dua indikator yang berbeda antara "komunikasi' dan "politik". Tentu memiliki konsep-konsep tersendiri, walaupun secara sederhana merupakan gabungan dari kedua konsep itu. 
Komunikasi dan politik dalam wacana ilmu pengetahuan memiliki dasar yang relatif. Tanpa ada ketergantungan dari ilmu masing-masing, ia memiliki konsep tersendiri. Namun, keduanya memiliki kesamaan sebab, akan tetapi memiliki objek material yang sama yaitu manusia. Dari kesamaan ini menjadikan keduanya memiliki koridor pertemuan bidang kajian yang interdisipliner dan di setiap disiplin ilmu membuka kajian kontekstualnya sendiri. Komunikasi menjadikan sebagai sub bagian yang mendalami dari ilmu lain. Sementara ilmu politik dilihat dari Bahasa “polis' yang mengandung arti negara, kota, yaitu kesatuan antara negara dan masyarakat.

Komunikasi politik merupakan kegiatan seseorang secara kolektif dengan melakukan pengaturan perbuatan mereka di dalam konflik sosial (Nimmo, 2004). Di setiap hal seseorang akan berbeda secara alamiah memiliki; jasmani, emosi, kebutuhan, cita-cita, perilaku dan lain sebagainya. Dari perbedaan tersebut merangsang motivasi, argumen, perselisihan, dan perdebatan. Apabila dianggap serius hal tersebut menjadikan suatu permasalahan bagi sekelompok orang, hal inilah yang mendasari kegiatan politik.

Kegiatan proses penyampaian politik melalui, komunikator politik, pesan politik, media atau saluran politik, sasaran atau target politik dan pengaruh atau efeknya (Cangara, 2009). Unsur-unsur tersebut dilakukan untuk memperoleh respon yang diharapkan untuk mempercepat pengambilan keputusan. Unsur yang akan dibahas lebih lanjut adalah berkaitan dengan komunikator politik, pesan politik, saluran politik dan efek pesan politik. Sesuai dengan kajian bahwa perang tagar di media virtual tak terlepas dari kajian komunikasi politik di ruang media dan aktor politik.

Proses yang terjadi di dalam sistem politik yang akan mengurai suatu peristiwa, bagaimana hubungan dan interaksi antara komunikator politik atau lembaga politik yang berinteraksi antara satu dengan lainnya. Dalam rangka membuat pesan politik (memperoleh, mempertahankan dan menyelenggarakan kekuasaan) melalui saluran-saluran yang biasa digunakan untuk penyampaian pesan politik kepada komunikan politik atau penerima pesan politik (khalayak politik), sehingga akan muncul efek (pengetahuan, perasaan, tindakan) dan sampai terjadi umpan baik yang ditujukkan kembali ke komunikator politik (dukungan atau penolakan). Komunikasi politik bisa dikatakan akan mengalami serangkaian siklus pembicaraan, mulai pembicaraan ringan, sedang dan krusial. Pembicaraan ringan tejadi bila masih terdapat satu pandangan dan kepentingan dalam bentuk konsultasi. Lalu menjadi pembicaraan yang sedang bila terjadi perbedaan pandangan, akan tetapi masih satu kepetingan dalam bentuk diskusi dan kompromi dan negosiasi. Pada tahap selanjutnya terjadi perbincangan yang krusial, yang akhirnya terjadi pembicaraan yang berbalut dengan perdebatan, emosi dan saling menghujat. Hal ini terjadi apabila terjadi perbedaan pandangan dan perbedaan kepentingan.

Hasil penelitian dan pengkajian tentang konten media dilakukan oleh Masyarakat Peduli Media (MPM), Lembaga Swadaya Masyarakat di Yogyakarta. Hasil Kajian menemukan sebagian besar konten atau pembahasan oleh para pendukung masing-masing kandidat hanya bernada negatif. Menurut Budi Hermanto, jika 1.541 percakapan Twitter para pendukung calon presiden dalam pemilihan umum tahun ini, sekitar 1.300 diantaranya atau $86,4 \%$ bernada negatif 
Ana Fitriana P, Ema, Fardiah Oktariani Lubis: Perang Tagar Di Ruang Virtual Diskursus Politik Capres Pasca Debat Putaran Kedua

dan menjelekkan pasangan calon presiden dan calon wakil presiden lain yang bukan pilihannya. Sedangkan untuk isi percakapan Twitter bernada positif hanya 13,6\%. (Azis. I, 2014).

Hadirnya new media atau media baru seperti Twitter dll, merupakan media yang menawarkan digitisation, convergence, interactiviy, dan development of network terkait pembuatan pesan dan penyampaian pesannya. Kemampuanya menawarkan interaktifitas ini memungkinkan pengguna dari new media memiliki pilihan informasi apa yang dikonsumsi, sekaligus mengendalikan keluaran informasi yang dihasilkan serta melakukan pilihan-pilihan yang diinginkannya. Kemampuan menawarkan suatu interkatif inilah yang merupakan konsep sentral dari pemahaman tentang new media (Flew \& Terry, 2002).

Munculnya virtual reality, komunitas virtual, identitas virtual merupakan fenomena yang banyak muncul seiring dengan hadirnya new media. Fenomena ini muncul karena new media memungkinkan penggunanya untuk menggunakan ruang seluas-luasnya di new media, memperluas jaringan seluas-luasnya, dan menunjukkan identitas yang lain dengan yang dimiliki pengguna tersebut di dunia nyata (Flew \& Terry, 2002).

Media sosial sebagai ruang publik berperan sebagai media untuk berdiskusi, bertukar pikiran, serta berkomunikasi secara bebas dan demokratis. Media sosial yang selayaknya berguna untuk membangun kebebasan berpendapat dan solidaritas demokrasi, justru digunakan sebagai alat penyebaran teks untuk menggiring opini publik, bahkan menyerang 'lawan' yang memiliki perbedaan pandangan dan ideologi (Kusumasari \& Arifianto, 2020). Selain itu, manfaat positifnya media sosial khususnya Twitter memberikan kemudahan untuk mendapatkan informasi secara cepat, singkat dan murah saat ini. Melalui media ini, bentuk-bentuk komunikasi pada penerapannya memberikan dampak yang signifikan pada proses kecepatan, persepsi pihak, ruang virtual untuk mengakses informasi seperti densitas dan kekayaan arus informasinya, serta jumlah fungsionalitas atau intelijen yang dapat dipublish (Kurnia, 2005).

Terpaan media, interaksi dalam media di abad informasi saat ini, seringkali membuat diri orang yang terlibat di dalamnya tak lebih dari bentukan media. Christoper Wulf dalam artikelnya "The Temporaly of WorldView dan Self Image," mengatakan bahwa pandangan dunia dan citra diri memang tak bisa dipisahkan. Cara manusia memandang dunia adalah cara menusia memandang dirinya, dan cara manusia memahami dirinya adalah cara manusia memahami dunia. Heidegger, dalam artikelnya "The Age Of World Picture" mengungkapkan bahwa dengan berkembangbiaknya citraan di dunia, maka dunia tempat manusia hidup tak lebih dari sebuah ontologi citraan. Citraan-citraan yang disajikan media, pada akhinya menjadi cermin tempat manusia berkaca, menunjukkan ekssistensinya (Piliang, 2004).

Kehadiran dunia virtual semakin mengukuhkan citraan-citraan yang dibentuk. Seyogyanya bahwa manusia saat ini sangat tergantung hidupnya dengan teknologi. Kehadiran internet yang diikuti dengan munculnya media sosial di dalamnya membawa pula berbagai masalah etika berkomunikasi. Penggunaan identitas palsu untuk kepentingan yang "negatif", penyebaran dan pengunduhan materi yang dilindungi hak cipta atau materi yang dilarang, merupakan hal yang 
melanggar etika dan dilarang. Namun kebebasan yang ditawarkan internet terutama dalam hal ini media sosial, seolah membuat matinya kepekaan etika. Apa yang harusnya tidak dilakukan, menjadi "nampak wajar" dilakukan. Bahkan tak jarang ada yang menganggapnya bukan suatu kesalahan dengan berbekal berbagai pembenaran yang dimunculkan.

Konsep dasar media sosial pada perkembangan mutakhir dari sebuah inovasi di situs atau platform baru berbasis internet. Sehingga dapat memudahkan bagi setiap orang untuk berkomunikasi, berpartisipasi, saling berbagi dan membentuk sebuah jaringan sosial secara online sebagai eksistensi diri (Zarella, 2010). Di antara bentuk media sosial yang paling populer yaitu microblogging atau Twitter yang membatasi ukuran unggahanannya dan memiliki fitur untuk menuliskan pesan-pesannya. Media Twitter merupakan salah satu jejaring sosial yang paling mudah digunakan, dengan waktu yang singkat, namun informasinya dapat dengan mudah disebar-luaskan.

Twitter memiliki konten yang menarik dan berbeda dengan media sosial lainya, seperti; memiliki halam utama (home), halaman ini bisa melihat unggahan yang dikirim oleh orang yang menjadi teman. Ada juga halaman utama atau timeline yang dapat menciptakan rangkaian tweet yang terorganisir sesuai dengan waktunya. Selanjutnya, tweet atau pesan, yaitu informasi yang ditulis dalam ruang virtual. Memiliki fungsi yang sama dengan update status, namun bedanya tweet hanya 140 karakter huruf. Halaman profile, pada halaman ini akan dilihat seluruh data diri serta tweet yang pernah dituliskan. Lalu, pengikut (follower) yaitu pengguna lain atau teman, jika sudah menjadi teman maka unggahan atau tweet teman bisa dilihat dan masuk ke dalam halaman utama. Membalas (reply) digunakan untuk membalas unggahan teman. Senarai (list), pengguna Twitter dapat mengelompokkan keanggotaan mereka ke dalam satu group, sehingga memudahkan untuk dapat melihat secara keseluruhan pengikut (username) yang mereka ikuti (follow). Topik hangat (trending topic), secara garis besar yaitu topik yang sedang banyak dibicarakan atau banyaknya pengguna dalam suatu waktu yang bersamaan. Kemudian secara spesifik kata, frase atau yang ditandai dengan tagar (\#) yang dilepaskan dengan kecepatan lebih tinggi, serta unggul dalam jumlah daripada kata, frase atau yang ditandai dengan tagar lainnya. Hal ini biasa dikatakan menjadi trending topic dan menjadi popular. Baik yang melalui upaya terpadu oleh pengguna atau karena suatu peristiwa yang mendorong orang untuk berbicara tentang satu hal tertentu.

Maka dari itu, keuntungan inilah yang banyak dimanfaatkan komunikator politik untuk meraih tujuannya. Komunikator politik akan berdampak pada pendukung fanatis yang melakukan penggiringan opini melalui sentimen-sentimen politik. Fenomena yang terjadi pasca debat politik Jokowi VS Prabowo mendapatkan tanggapan yang beragam dari warganet fanatik dari kedua kubu. Selain kesalahan data, yang disebutkan oleh Jokowi juga topik unicorn yang ditanyakan oleh Prabowo, menjadi perdebatan menarik di ruang virtual. Yang akhirnya menjadi trending topik antara tagar "\#JokowiBohongLagi dan \#02GagapUnicorn. 
Untuk mendapatkan informasi lebih mendalam, kerangka analisis menggunakan Critical discourse analysis (CDA), dalam riset komunikasi dipakai untuk mengungkap ideologi yang tersembunyi dalam teks, dengan menelanjangi asumsi-asumsi kebenaran yang kerap menjadi pemikiran umum dalam masyarakat. Critical discourse analysis mengungkap ketidakberesan dalam masyarakat dengan menemukan sumber dan penyebabnya (ketidakadilan, ketidak setaraan, diskriminasi, ketidakbebasan) tersebut, kemudian menemukan cara untuk melawannya. Untuk itu, CDA dikatakan bersifat kritis, karena tradisi kritis dalam analisis sosial ke-dalam studi bahasa memiliki kontribusi pada analisis sosial kritis, yang fokus pada wacana, dan hubungan antara wacana dan elemen sosial lainnya (kekuasaan, ideologi, institusi dan identitas sosial). Analisis sosial kritis bersifat normatif dan jelas (Fairclough, 2013).

Membekukan konsepsi kekuasaan, menggunakan konsep hegemoni NeoGram-scian, yang berbicara mengenai konstruksi dan dekonstruksi koalisi politik, serta stabilisasi praktik dan rezim kebijakan ke dalam beberapa blok dan perencanaan historis yang tetap (Howarth, 2010). Pada intinya penelitian yang menggunakan CDA, peneliti berada dalam posisi berpihak, semata-mata untuk membongkar dan mendemistifikasi dominasi yang terdapat dalam wacana. Ada tanggung jawab moral dan politik pada mereka yang melakukan CDA (Haryatmoko, 2016).

Fairclough menggunakan wacana menunjuk pada pemakaian bahasa sebagai sebuah praktik sosial, lebih daripada aktivitas Individu atau untuk merefleksikan sesuatu. Pertama, wacana adalah bentuk dari tindakan, seseorang menggunakan bahasa sebagai suatu tindakan pada dunia dan khususnya sebagai bentuk representasi dari realita yang ada. Kedua, implikasi adanya hubungan timbal balik antara wacana dan struktur sosial (Eriyanto, 2001).

Analisis CDA dikelompokkan menjadi tiga dimensi, masing-masing memiliki fokus yang berbeda-beda. Ketiga dimensi tersebut yaitu; 1) Mikrostruktural (mikro) atau narasi debat dan tweet warganet, pada dimensi ini berfungsi untuk merepresentasi muatan ideologi yang ingin ditampilkan (ideasional), menunjukkan konstruksi hubungan antar teks dengan proses diseminasinya (relasional), dan menunjukkan konstruksi identitas pembuat teks dan kepentingannya. Bagaimana personal dalam identitas ditampilkan (identitas). 2) Mesostruktur (messo) atau praktik diskursif, yaitu semua bentuk produksi dan konsumsi teks. Dalam dimensi ini ada proses menghubungkan produksi dan konsumsi teks atau sudah ada interpretasi. Fokusnya diarahkan pada cara pengarang teks mengambil wacana dan genre yang ada dengan memperhatikan bagaimana hubungan kekuasaan dimainkan. 3) Makrostruktural (makro), dimensi ini dilakukan terhadap konteks di luar teks, misalnya dengan aspek sosial dan budaya yang berlaku ketika itu.

\section{Metode Penelitian}

Metode penelitian yang digunakan menggunakan metode deskriptif kualitatif. Deskriptif kualitatif sebagai prosedur penelitian yang menghasilkan data berupa data naratif secara tertulis (Subandi, 2011). 
Metode ini bertujuan untuk menjelaskan atau mendeskripsikan fenomenafenomena yang hendak diungkap, bersifat alamiah maupun hasil rekayasa manusia. Selain itu, kualitatif deskriptif tidak membuat perlakuan khusus atau manipulatif, melainkan menjelaskan kondisi sesuai dengan keadaan. Salah satu cara untuk menghasilkan datanya melalui observasi, secara linguistis karena ingin melihat bagaimana seuatu realitas itu ditampilkan atau dibentuk dalam teks yang bisa jadi membawa pada ideologis tertentu, bagaimana penulis mengonstruksi hubungannya dengan pembaca (baik secara formal atau informal, tertutup atau terbuka), dan bagaimana suatu identitas itu hendak ditampilkan (identitas penulis dan pembaca), artinya dalam analisis teks ini meliputi representasi, relasi, dan identitas. (2) Discourse practice merupakan dimensi yang berhubungan dengan proses produksi dan konsumsi teks. Proses produksi teks lebih mengarah pada si pembuat teks tersebut. Proses ini melekat dengan pengalaman, pengetahuan, kebiasaan, lingkungan sosial, kondisi, keadaan, konteks, dan sebagainya yang dekat pada diri atau dalam si pembuat teks.

Sementara itu, untuk konsumsi teks bergantung pada pengalaman, pengetahuan, konteks sosial yang berbeda dari pembuat teks atau bergantung pada diri pembaca/penikmat. Bagaimana cara seseorang dapat menerima teks yang telah dihadirkan oleh pembuat teks. Kaitannya dalam distribusi teks, yaitu sebagai modal dan usaha pembuat teks agar hasil karyanya dapat diterima oleh masyarakat. (3) Socio-cultural practice adalah dimensi yang berhubungan dengan konteks diluar teks. Seperti konteks situasi. Konteks yang berhubungan dengan masyarakat, atau budaya, dan politik tertentu yang berpengaruh terhadap kehadiran teks.

Proses analisis data lebih kepada mendeskriptifkan konten-konten media sosial Twitter dengan proses analitik, mengumpulkan dan penyusunan analisis data. Analisis yang digunakan menggunakan metode analisis wacana kritis Norman Fairclough yang meliputi teks, discourse practice, dan sociocultural practice. Setelah dilakukan analisis, selanjutnya penyajian hasil analisis data berdasarkan pada penemuan data yang sudah dilakukan pada tahap awal. Hasil analisis

disampaiakan secara naratif dan disajikan secara deskriptif untuk memudahkan dalam mendapatkan hasil penelitian. Data yang sudah terkumpul akan disajikan berdasarkan uraian yang mudah dipahami berdasarkan teori yang dipakai.

\section{Hasil Penemuan dan Diskusi}

Analisis data merujuk pada hasil debat Pilpres 2019 putaran kedua, Jokowi VS Prabowo yang bertarung dalam kontestasi politik. Hasil debat menjadi pertentangan publik melalui media sosial Twitter.

Pada level mikro analisis ini dikhususkan pada pendalaman materi debat yang berujung pada sentimen tweet warganet di Twitter. Materi debat menjadi modal dalam menginterpretasi sentimen pada masing-masing kubu yang berujung pada perang tagar di media virtual. Berikut materi debat dan tweet warganet yang dianalisis; 
Tabel 1. Narasi Debat Capres 2019 Putaran Kedua Yang Menjadi Perdebatan

\begin{tabular}{|c|c|c|}
\hline No & Capres 01 & Capres 02 \\
\hline 1. & $\begin{array}{l}\text { "Berkaitan dengan bidang } \\
\text { infrastruktur. Kita tahu dalam } \\
\text { tiga tahun ini telah kita } \\
\text { gelontorkan seratus delapan } \\
\text { puluh tujuh triliun dana desa ke } \\
\text { desa desa. Apa yang kita } \\
\text { dapatkan dari dana ini? Telah } \\
\text { dibangun seratu sembilan } \\
\text { puluh satu ribu kilometer jalan } \\
\text { di desa." }\end{array}$ & $\begin{array}{l}\text { Prabowo sempat terkesan meraba-raba soal } \\
\text { Unicorn yang dimaksud Jokowi. "Maksudnya } \\
\text { yang online-online," ujar Prabowo yang } \\
\text { dijawab Jokowi dengan anggukan. } \\
\text { Prabowo menyebutkan sangat mendukung soal } \\
\text { dorongan untuk Unicorn, tapi Prabowo tidak } \\
\text { menjawab apa yang akan dilakukan. }\end{array}$ \\
\hline 2. & $\begin{array}{l}\text { "Dua ribu empat belas kita } \\
\text { masih impor tiga koma lima } \\
\text { juta ton jagung tahun dua ribu } \\
\text { delapan belas kita hanya impor } \\
\text { seratus delapan puluh ribu ton } \\
\text { jagung." }\end{array}$ & $\begin{array}{l}\text { Prabowo akui kuasai tanah HGU, daripada } \\
\text { dikuasai asing. Prabowo menyatakan dirinya } \\
\text { memiliki strategi tersendiri, terutama terkait } \\
\text { mengatasi ketimpangan. } \\
\text { "Tapi itu HGU (hak guna usaha), kalau suatu } \\
\text { saat diperlukan negara silakan ambil," ujar } \\
\text { Prabowo. Tapi, lanjut Prabowo, daripada } \\
\text { dikuasai asing, lebih baiklahan itu dikuasai oleh } \\
\text { dirinya }\end{array}$ \\
\hline 3. & $\begin{array}{l}\text { "Sebuah lompatan besar } \\
\text { bidang lingkungan hidup kita } \\
\text { ingin kebakaran hutan } \\
\text { kebakaran lahan gambut tidak } \\
\text { terjadi lagi dan ini sudah bisa } \\
\text { kita atasi dalam tiga tahun ini } \\
\text { tidak terjadi kebakaran lahan, } \\
\text { hutan, kebakaran lahan } \\
\text { gambut." }\end{array}$ & \\
\hline
\end{tabular}

Sumber materi Debat Capres 2019 Putaran Pedua.

Dari beberapa narasi debat tersebut dapat dianalisis yang menjadi bahan untuk perdebatan di ruang media virtual. Masing-masing kubu warganet mengembangkan argumentasinya sesuai narasi yang dibacakan masing-masing kandidat. Berikut analisis tweet warganet yang menjadi bahan analisis;

\section{Analisis Tweet Warganet Pendukung Capres \#02}

1. Sang KolonelTM@cakrabirawa2000

Sudah diucapkan terus salah, ya minta maaf kalau cuma diralat tanggung mending langsung aja \#DeleteJokowi atau \#UinstallJokowi jadi gak akan lagi ada yang tau apa yang sudah disampaikan saat debat kemarin. Kenapa sih harus \#BohongLagiJokowiSekarang. \#NewEraPrabowoSandi.

Representasi, proses penyampaian makna dengan penyampaian kebohongan yang perlu di ralat dengan meminta maaf. Relasi, berkaitan dengan kontek dukungan terhadap Capres 02 yang melakukan kritik terhadap kubu lawan. Identitas, menggunakan simbol tagar \#DeletJokowi, \#UninstallJokowi, 
\#BohongLagiJokowiSekarang dan \#NewEraPrabowoSandi sebagai komunikasi visual.

2. @Akun-Bojonggede.

Haduh pak Jokowi fatal banget bohong saat debat capres. Ditonton banyak orang

pak-_- \#JokowiBohong. 365 Retweets 21 Likes.

Representasi menempatkan pelaku utama di awal klausa kalimat, sehingga berdampak pada subjek. Relasi, tweet warganet pendukung Capres 02 dengan membangun narasi sentimen terhadap kubu lawan. Identitas, menggunakan simbol tagar \#JokowiBohong sebagai representasi komunikasi visual.

3. Indonesia Menang @pollingbangsa.

Ini menunjukkan debat beliau dipersiapkan untuk menyerang lawan, ketimbang menjawab persoalan negara. Hhhmmmm masuk akal juga.

\#CapresO1Bohong.

\#BohongLagiJokowi. \#PrabowoOrangnyaBaik\#CapresPebohongKelautAje.

\#JokowiTheLIAR. \#SetelahDebatSemalam. \#prabowobicarabenar.

Representasi dari pemaparan Capres 01 dipersiapkan untuk menyerang lawan dibandingkan untuk memberikan solusi. Menggunakan tata bahasa 'beliau' dengan penajaman kata di pertajam dengan penajaman makna 'menyerang lawan' untuk memperburuk citra lawan lalu menggunakan kata 'bukan menjawab persoalan bangsa' artinya tidak memberikan solusi dalam debat ini. Relasi berkaitan dengan respon atas pernyataan Capres 01 yang lebih banyak menyerang lawan. Identitas menggunakan simbol tagar, \#CapresO1Bohong, \#BohongLagiJokowi, \#Pra-bowoOrangnyaBaik, \#CapresPembohongKelautAje, \#JokowiTheLIAR, \#SetelahDebatSemalam dan \#prabowobicarabenar sebagai komunikasi visual.

4. Kampus_Inspirasi@Kampus_Merdeka

Kebohongan Rezim terus berlanjut. Konflik Agraria di Era Jokowi: 41 Orang Tewas, 546 dianiaya. Bukan tidak ada, sebagaimana diucapkan saat debat \#Bohonglagi. \#LagiLagiBohong orang baik tidak bohong.

\#PrabowoMenangDebat

\#PrabowoIndonesiaMenang

\#NewEraPrabowoSandi.

Representasi dari pernyataan Capres 01 ketika debat bahwa, "Tidak ada lagi konflik Agraria, akan tetapi nyatanya masih terjadi konflik Agraria. Menurut data di era Jokowi sekitar 41 orang tewas, 546 dianiaya. Warganet menganggap bukan tidak ada sebagaimana diucapkan ketika debat, sehingga mereka menyimpulkan bahwa Capres 01 bohong. Relasi komunikasi, melakukan klarifikasi data terhadap kesalahan penyampaian data ketika debat, terkait konflik agrarian. Identitas menggunakan simbol tagar \#Bohonglagi, \#LagiLagiBohong, 
Ana Fitriana P, Ema, Fardiah Oktariani Lubis: Perang Tagar Di Ruang Virtual Diskursus Politik Capres Pasca Debat Putaran Kedua

\#PrabowoMenangDebat, \#PrabowoIndonesia-Menang,

dan \#NewEraPrabowoSandi sebagai komunikasi visual.

5. JUNDIWARRIOR @jundiwarrior.

Jokowi:"Selama 3 tahun ini tdk ada kebakaran hutan." Detik: Tgl : 15 Feb 2019

"Kebakaran Lahan Di Riau Meluas"

\#bohongLagi

\#DebatPilpres2019

\#Debatke2

\#Debat02PrabowoMenang

Representasi dari pernyataan Capres 01, "Selama 3 tahun ini tadak ada kebakaran hutan." Nyatanya jika dilihat melalui pemberitaan media Detik.com pada tanggal 15 Februari 2019 "Kebakaran lahan di Riau meluas." Relasi berkaitan dengan tweet warganet pendukung 02 yang lebih mengkerdilkan kesalahan data Paslon 01 saat debat. Identitas, menggunakan simbol tagar \#bohongLagi, \#DebatPilpres2019, \#Debatke2 dan \#Debat02PrabowoMenang sebagai dukungan dan komunikasi visual.

6. IKUT ULAMA GARIS LURUS@ marinarambe.

Jokowi: 26 September tidak akan ada impor beras, 11 November beras import tiba di Tanjung Priuk \#BohongLagi cc@ypaonganan

@IwanPiliang7

@ peppramu

Representasi dari pernyataan, "Jokowi pada tanggal 26 September tidak akan ada import beras, akan tetapai kenyataannya pada tanggal 11 November beras import tiba di Tanjung Priuk. Relasi berkaitan dengan kekecewaan atas janji politik terhadap Paslon 01. Identitas, melakukan penegasan mealalui tagar \#BohongLagi cc@ypaonganan, @IwanPiliang7, @peppramu sebagai komunikasi visual antar pendukung.

7. NataliusPigai@NataliusPigai2.

Ira Kusno, presenter, moderator debat Pilpres terbaik, objektif dan profesional. Poling secara langsung melalui Trans7 saat debat berlangsung. Prabowo 82\% dan Jokowi 18 \%. Apakah fakta ini mau dibantah? Akhirnya juga rakyat Indonesia yang menentukan Pilihan (Natalius P).

Representasi dari hasil debat dimulai dari apresiasi kepada presenter atau moderator yang objektif dan profesional. Membangun narasi melalui hasil poling Trans7, yang hasilnya menunjukan Prabowo 82\% dan Jokowi 18\%. Mereka mempertanyakan narasi dari data tersebut yang tidak dapat dibantah. Selanjutnya menggiring opini untuk mengambil sikap dalam menentukan pilihan pada Pemilu kali ini. Relasi menunjukan bahwa klaim kemenangan Paslon 02 sudah jelas. Identitas, mengungkapkan data hasil poling melalui media sosial sebagai peneguhan data. 
8. Akal Sehat @ Rockygerung_.

SELANG SEMENIT KEMUDIAN JOKOWI BILANG LAGI, "ARTINYA YANG NGANGGUR BISA GUNAKAN KARTU ITU. Blunder oh blunder, cebong dan anak keturunannya mungkin yg paham.

\#JokowiXCakLontong

\#JokowiBohong

\#KartuPraKerja

\#DebatCapres

\#17April2019GantiPresiden

\#AkalSehat.

Representasi terhadap pernyataan Paslon 01, "pengangguran bisa menggunakan kartu pencari kerja." Membangun narasi yang membuat kebingungan atas program yang dianggap blunder atau membingungkan. Menggunakan istilah Cebong dan anak keturunannya yang hanya memahami program tersebut. Relasi komunikasi menggunakan istilah Cebong dan anak keturunannya sebagai bentuk pernyataan pengkerdilan kubu lawan. Identitas komunikasi menggunakan simbol tagar, \#JokowiXCak-Lontong, \#JokowiBohong, \#KartuPraKerja, \#DebatCapres, \#17April2019GantiPresiden dan \#AkalSehat sebagai komunikasi virtual.

9. Indonesia Adil @BangRW_.

Woibong,omongan @ TitiekSoeharto

ini benar, masuk akal. Gak kayak junjunganmu yang bisanya bohong2. Mending

kita lanjutkan program Pak Harto yang pernah dicapai Orba dulu

\#AntiRezimKodok \#JokowiBohong.

Representasi dari narasi sisnis terhadap kubu pendukung 01 dengan menggunakan istilah 'Woi Bong'. Membenarkan narasi yang dibangun oleh Titiek Soeharto mantan istri Paslon 02 yang masuk akal. Lalu membuat perbandingan dengan menggunakan metafora 'junjunganmu' yang bisanya bohong-bohong. Menurutnya lebih baik melanjutkan program Pak Harto yang pernah berhasil. Relasi komunikasi berkaitan dengan Identitas komunikasi visual melalui tagar \#AntiRezimKodok dan \#JokowiBohong sebagai komunikasi visual.

10. Eriya Lingga Pratama @eriyalggapratama.

\#JokowiBohong aduh pagi2 sdh rame aja twitter tentang pak jokowi, rezeki atau musibah nih yg dihadapi pak jokowi, ambil hikmahnya aja.

Representasi komunikasi sebagai pendukung Paslon 02 dengan membangun narasi tentang situasi yang ramai terkait kebohongan yang dilakukan oleh Paslon 01 dengan mengilustrasikan dengan rezeki atau musibah. Pada akhir kalimat membangun makna "Ambil hikmahnya aja" sebagai relasi komunikasi meneguhkan subjek untuk berfikir. Identitas komunikasi menggunakan simbol tagar \#JokowiBohong sebagai komunikasi virtual. 


\section{Analisis Tweet Warganet Pendukung Capres \#01}

1. Adi @ rachmatafriadip.

Seorang pemimpin yang cerdas sih seharusnya memiliki pengetahuan yang luas terkait banyak hal, kegagapan dalam informasi buat pemimpin setingkat Presiden mah bakalan malu-maluin bangsa sendiri.

Upgrade lagi deh pak @prabowo informasinya, biar tidak gagap. \#02GagapUnicorn.

Representasi penggunaan kata diksi yang menyatakan ketidaktahuan paslon 02 terkait Unicorn, yang menjadi tren di kalangan milenial. Relasi, berkaitan dengan kontek dukungan terhadap Paslon 01, dengan mengunggah sentimen terhadap lawan. Identitas komunikasi menggunakan simbol komunikasi Upgrade @ prabowo informasinya dan menggunakan tagar \#02GagapUnicorn sebagai komunikasi virtual.

\section{Generasi Milenial}

Wajib pilih Presiden yang ngerti milenial. Masa Unicorn aja gak paham? Infrastruktur digital gak paham? e-comer e-ini e-itu yg onlen-onlen \#02GagapUnicorn.

Representasi komunikasi penggunaan repetisi kata milenial sebagai peneguhan kata. Kalimat berikutnya menggunakan kalimat tanya sebagai bentuk untuk memarjinalkan objek dan memperolok subjek. Relasi komunikasi pernyataan 02 dalam debat dengan tema Unicorn, menimbulkan reaksi argumentatif. Identitas, menggunakan simbol tagar \#02GagapUnicorn sebagai komunikasi virtual.

\section{Suara Hati@7intaPutih.}

Wowo Gendereuwo menepuk air di dulang. Koar-koar pasal 33 tidak taunya diri sendiri lebih parah. Ngaku-ngaku adil makmur tidak taunya serakah. Balikin hoii tanah negara. Dasar penjajah \#CapresO2Ngibul

\#02GagapUnicorn.

Representasi, obejek digambar sebagai 'Wowo genderuwo' makhluk seram sebangsa Jin. Kontruksi peristiwa yang dicitrakan baik namun ternyata sebaliknya. Relasi, respon warganet pendukung 01 terhadap reaksi penguasaan tanah oleh Paslon 02. Identitas, menggunakan simbol tagar \#Capres02Ngibul dan \#02GagapUnicorn sebagai komunikasi virtual.

\section{Surya Dewi Citra @ SuryaDewiCitra2}

Pak@jokowi emang the best lah, 7 ruas tol Trans Jawa yang diresmikan hari ini: Tol Pemalang-Batang Seksi 1\&2 SS 34 km. Tol Batang-Semarang Seksi 1$575 \mathrm{~km}$. Tol Semarang-Solo seksi 4\&5 Salatiga-Kartasura $33 \mathrm{~km}$

\#01IndonesiaMaju

\#DebatPintarJokowi

\#LebihBaikJokowi

\#01IndonesiaMaju 


\author{
\#02GagapUnicorn \\ \#JokowiOrangBaik \\ \#JokowiLagi \\ \#generasioptimis \\ \#JokowiOrangnyaBaik \#DebatPintarJokowi \\ \#JokowiMenangLagi \\ \#02GagapUnicorn \\ \#01JokowiLagi \\ \#DebatPintarJokowi.
}

Representasi komunikasi dari pembangunan infrastruktur masa jabatan Paslon 01 saat pada periode pertama. Capaian pembangunan infrastruktur jalan tol lintas Jawa berhasil dibangun hingga $142 \mathrm{~km}$. Relasi komunikasi warganet pendukung 01 mengeluarkan pernyataan atas dukungan terhadap Paslon 01 dengan mengkerdilkan Paslon 02. Identitas komunikasi penggunaan simbol visual tagar, \#01IndonesiaMaju, \#DebatPintarJokowi, \#Lebih-BaikJokowi, \#01IndonesiaMaju, \#02Gagap-Unicorn, \#JokowiOrangBaik, \#JokowiLagi, \#ge-nerasioptimis, \#JokowiOrangnyaBaik, \#Debat-PintarJokowi \#JokowiMenangLagi, \#02GagapUnicorn, \#01Joko-wiLagi, dan \#DebatPintar-Jokowi sebagai komunikasi virtual.

5. Chusnul chotimah@CH_chotimah

Kalau bagus, ya harus saya katakan bagus. Kali ini saya setuju dengan Pak Jokowi, kata wowo (2014).

Kalau demikian prestasi bapak (Jokowi) Saya harus akui dan menghargai serta mendukung,

Kata wowo (2019)

Tanda2 \#2019TetapJokowi

\#DebatPintarJokowi

\#DebatKeduaPilpres2019.

Representasi komunikasi dari akun @ CH_chotimah membangun narasi tentang pengakuan Capres 02 terhadap Capres 01 ketika debat di tahun 2014 lalu dan sekarang. Pernyataan yang mengandung sentimen mendukung paslon nomor urut 01. Relasi komunikasi menggunakan istilah wowo dan membangun narasi dari pernyataan kandidat lawan. Identitas komunikasi, menggunakan tagar \#2019TetapJokowi, \#DebatPintarJokowi dan \#DebatKeduaPilpres2019 sebagai simbol komunikasi virtual.

6. Mr. Toe Gaz. @dewo_lelon.

Replying to@marierteman 2014, TPID prabowo tidak tau 2019, Unicorn Prabowo tidak paham \#PrabowoGagap-Unicorn ini malah mbahas Tol langit, Ealah,,, belum nyampek pak,, serahkan saja pada ahlinya pak.

Representasi komunikasi dari akun @ dewo_lelon yang membangun narasi tentang pemahaman Prabowo yang kurang memahami tentang Unicorn, yang masuk kedalam proyek Tol Langit. Suatu istilah infrastruktur di udara melalui 
Ana Fitriana P, Ema, Fardiah Oktariani Lubis: Perang Tagar Di Ruang Virtual Diskursus Politik Capres Pasca Debat Putaran Kedua

jaringan internet. Relasi komunikasi sebagai warganet pendukung Jokowi. Identitas komunikasi menggunakan simbol tagar \#PrabowoGagap-Unicorn sebagai komunikasi virtual.

7. Ignatio_Dee @IgnatioDee-Replying to @ RajaPurwa, @cumarachel and @ prabowo.

Akui aja, capres jagoanmu itu bodoh, gak paham soal bangsa ini, yg terjadi di kekinian yo gak paham. Timsesnya juga bodoh, pinternya Cuma bikin hoax aja. Di 2014 dulu TPID aja juga gak tahu kan??? Cuma modal ngomong menggelegar doank tanpa paham makna.

\#PrabowoGagapUnicorn.

Representasi dari akun milik @IgnatioDee yang sudah dibagikan ke @RajaPurwa, @cumarachel and @ prabowo. Membangun narasi atau sentimen melalui pengakuan capres dukungan kubu lawan kurang membaca. Dianggap tidak memahami persoalan bangsa. Lalu menggiring kepada tim suksesnya yang dianggap sama, akan tetapi hanya bikin hoax. Melakukan pengkerdilan dengan menyatakan suaranya saja menggelegar tapi pengetahuannya dianggap kosong. Relasi berkaitan dengan dukungan terhadap Paslon 01. Identitas menggunakan simbol tagar \#PrabowoGagapUnicorn sebagai komunikasi virtual.

8. Melody Irene @ meloyren. Feb 25

Replying to @CepotRezim @D4Ni3L_Pu and 6 others.

TENGGELAMKAN \#Prabohong YANG MEMBUAT RAKYAT SEMAKIN

TAKUT KALAU DIA JADI PEMIMPIN !!!

\#BalikinUntukRakyat \#prabowotuantanah

\#PrabowoTakutKalender

\#PRABOWOGAGAPUNICON

\#Prabohoax

\#Prabohongstadium4

\#wowoAntekAsing

\#wowocapresabadi

\#sandiwarauno

\#SandiwaraAnakMami

\#sandiwaramanjah

Representasi dari narasi 'tengelamkan' dengan menggunakan hurup kapital sebagai penegasan kata dan makna. Tagar \#Prabohong dianggap menakutkan bila menjadi presiden. Relasi sebagai warganet pendukung kubu 01 dengan membuat pernyataan mengerdilkan atau menjatuhkan lawan. Identitas menggunakan simbol tagar \#Prabohong, \#BalikinUntukRakyat, \#prabowo-tuantanah, \#PrabowoTakutKalender, \#Prabowo-GagapUnicorn, \#Prabohoax, \#Prabohongstadium4, \#wowoAntekAsing, \#wowocapres-abadi, \#sandiwarauno, \#SandiwaraAnakMami, \#sandiwaramanjah sebagai komunikasi virtual. 
9. CINTA INDONESIA @kameswara_aja.Feb 19

Kaтu, iyaa kamu balikin dong lebihan tanahnya negara, bayar dong tunggakan pajak dan pinjaman lunaknya yang besar dan makin melunak itu *eh \#PrabowoTuanTanah \#prabowohutang \#prabowogagapUnicorn.

Representasi komunikasi dari narasi tentang kepemilikan tanah Paslon 02, diminta untuk mengembalikan ke-Negara. Ditambah dengan narasi menunggak pajak dan pinjaman Paslon 02. Relasi komunikasi pernyataan dukungan terhadap Paslon 02 dengan mengkerdilkan Paslon lawan. Identitas komunikasi menggunakan simbol tagar \#PrabowoTuanTanah, \#prabowohutang dan \#prabowogagapUnicorn sebagai komunikasi visual virtual.

\section{MamanyaIntanIYK}

@BundanyaINTANYK $\cdot$ Feb 19

Replying to @ saididu and @jokowi

Kubu dua udah tau Nggak bakal laku. Kubu dua ketinggalan jauh daur kubu satu!

\#Jokowil KaliLagi \#JokowiHarapanPasti

\#JokowiDebatpintar

\#PrabowoGagapUnicorn

\#Prabowogaptek

Representasi komunikasi melalui narasi Capres 02 yang dianggap tidak laku dan ketinggalan jauh dengan Capres 01. Relasi sebagai warganet pendukung 01 yang dianggap menang. Identitas komunikasi menggunakan simbol tagar \#Jokowi1KaliLagi, \#JokowiHarapanPasti, \#Jo-kowiDebatpintar, \#PrabowoGagapUnicorn dan \#Prabowogaptek sebagai komunikasi virtual.

Dari hasil analisa bahwa interpretasi komunikasi tweet warganet pendukung 02 banyak menggunakan kata ganti objek, frasa, diksi dan penempatan pelaku utama di awal kalimat. Kata ganti subjek menggunakan istilah Mukidi, juga dipertajam dengan tagar \#DeleteJokowi dan \#UnistallJokowi. Debat 01 dipersiapkan untuk menyerang dibandingkan untuk memberikan solusi. Sebaliknya, tweet warganet pendukung 01 lebih banyak menggunakan kata diksi, yang merepresentasikan ketidaktahuan 02 terkait Unicorn, platform yang menjadi tren di kalangan milenial. Repetisi pada kata milenial, untuk mempertegas makna, diperkuat dengan kalimat tanya secara berulang untuk memperolok subjek. Representasi komunikasi dari Paslon 02 digambarkan sebagai sosok yang temperamental dan dikontruksikan sebagai sosok yang menyeramkan. Data tentang konflik agraria yang menyatakan bahwa tidak ada lagi konflik agraria, akan tetapi nyatanya masih terjadi konflik, di era Jokowi sekitar 41 orang tewas, 546 dianiaya. Selanjutnya, Paslon 01 "Selama 3 tahun ini tidak ada kebakaran hutan," namun Detik:Tgl:15 Feb 2019 "Kebakaran lahan di Riau meluas." Data tentang "Jokowi pada tanggal 26 September tidak akan ada import beras, namun pada tanggal 11 November Beras Import tiba di Tanjung Priuk. Apresiasi terhadap presenter atau moderator saat debat kedua yang terbaik, objektif dan profesional. Sebagai peneguhan atas dukungan terhadap Paslon 02 dengan membangun narasi 
Ana Fitriana P, Ema, Fardiah Oktariani Lubis: Perang Tagar Di Ruang Virtual Diskursus Politik Capres Pasca Debat Putaran Kedua

kemenangan debat yang dirilis oleh Trans7. Hasilnya Prabowo 82\% dan Jokowi 18 $\%$. Lalu menggiring opini untuk memutuskan pilihan pada salah satu kandidat paslon. Narasi tentang pengangguran bisa menggunakan kartu pencari kerja program ini dianggap membingungkan saat disampaikan. Penggunaan istilah Cebong dan anak keturunannya yang memahami programnya, hal ini menunjukan utuk mengkerdilkan lawan. Menggunakan narasi panggilan 'Woi Bong' sebagai pembenaran atas teks Titiek Soeharto yang lebih masuk akal diabnding program Paslon 01. Menggunakan metafora 'junjunganmu' yang biasanya bohong-bohong. Menurutnya lebih baik melanjutkan program Pak Harto yang pernah berhasil ketimbang mendukung program yang dibangun 01. Membangun narasi yang seolah kondisi sedang ramai terkait kebohongan yang dilakukan oleh Paslon 01 dengan mengistilahkan rezeki atau musibah.

Relasi komunikasi berkaitan dengan tweet warganet pendukung 02 yang menuliskan sentimen terhadap pendukung 01. Kesalahan data Paslon 01 dianggap fatal oleh pendukung 02. Sementara, tweet warganet pendukung 01 lebih membahas isu tentang Unicorn dan penguasaan tanah. Dimulai ketika pemaparan 02 yang dianggap tidak memahami materi debat. Warganet pendukung 01 menganggap bahwa Paslon 02 akan ditinggalkan oleh pendukung Milenial yang saat ini sedang menggandrungi platform tersebut, sehingga nantinya 02 bisa kehilangan suaranya. Klarifikasi data terhadap kesalahan penyampaian Paslon 01 saat debat tentang konflik agrarian. Sebagai bentuk dukungan terhadap kandidat no 2 dengan mengungkapkan data hasil poling melalui media sosial sebagai peneguhan data dan penggiringan opini untuk memilih salah satu paslon kandidat. Membangun narasi tentang pengakuan Capres 02 terhadap Capres 01 ketika debat di tahun 2014 lalu dan sekarang. Pernyataan-pernyataan yang mengandung sentimen mendukung paslon nomor urut 01. Pemahaman 02 yang kurang memahami tentang Unicorn, yang masuk kedalam proyek Tol Langit istilah infrastruktur di udara melalui jaringan internet. Pengakuan bahwa capres dukungan kubu lawan bodoh, yang dianggap tidak memahami persoalan bangsa. Lalu menyudutkan timsesnya juga yang dianggap sama, hanya dapat membuat hoax. Melakukan pengkerdilan dengan menyatakan suaranya saja menggelgar pengetahuannya dianggap kosong.

Membangun narasi tentang Capres 02 yang dianggap tidak laku dan dianggap sudah ketinggalan jauh dengan Capres 01. Kepemilikan tanah oleh Paslon 02 diminta untuk dikembalikan kepada Negara. Lalu membangun narasi tentang Capres 02 menunggak pajak dan pinjaman. Tengelamkan dengan hurup capital sebagai pebegasan kata dan makna \#Prabohong dianggap menakutkan bila menjadi presiden.

Identitas komunikasi penggunaan simbol-simbol yang melekat di setiap tweet narasi yang dibuat, merujuk pada identitas subjek yang memiliki kepentingan. Istilah Cebong, Mukidi, Hoax dan Tagar \#DeletJokowi, \#UinstallJokowi, \#JokowiBohong, \#BohongLagiJokowi, \#CapresO1Bohong, \#PrabowoOrangnyaBaik, dan \#NewEraPrabowoSandi \#Bohonglagi, \#LagiLagiBohong, \#PrabowoMenangDebat \#Prabowo-IndonesiaMenang, \#NewEraPrabowoSandi, \#BohongLagi, \#AntiRezimKodok, \#bohongLagi, \#DebatPilpres2019, \#Debatke2, \#Debat02Prabowo-Menang, \#JokowiXCakLontong, \#JokowiBohong, \#KartuPraKerja, \#DebatCapres, 
\#17April2019GantiPresiden dan \#AkalSehat mengintegrasikan persepsi dan perdebatan di antara kubu warganet. Sementara, tweet pendukung Paslon 01 menggunakan simbol tagar, \#01IndonesiaMaju, \#DebatPintarJokowi, \#LebihBaikJokowi, \#01IndonesiaMaju, \#02GagapUnicorn, \#Capres02Ngibul, \#JokowiOrangBaik, \#JokowiLagi, \#JokowiMenangLagi dan \#01JokowiLagi sebagai simbol komunikasi virtual.

Proses produksi dan reproduksi teks (messo) lebih kepada analisis yang berhubungan dengan bagaimana pemrosesan wacana yang meliputi aspek penghasilan, penyebaran dan penggunaan teks. Aspek ini lebih kepada bagaimana para warganet masing-masing kandidat melakukan perdebatan atau sentimen di ruang media. Proses analisis terdiri dari produksi teks, wacana teks terbagi ke dalam dua bagian antara kubu 01 dan 02, yaitu Cebong dan Kampret. Cebong dikhususkan kepada pendukung 01 Jokowi-Ma'ruf, sedangkan Kampret untuk pendukung 02 Prabowo-Sandi. Setiap pernyataan kandidat yang menjadi titik lemah menjadi bahan sentimen di masing-masing kubu di media sosial.

Proses produksi warganet pendukung Paslon 02 menggunakan tagar (\#)

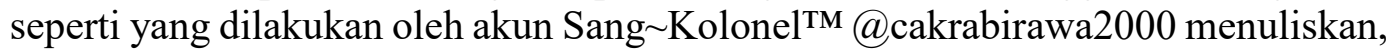
\#DeleteJokowi atau \#UninstallJokowi, \#BohongLagiJokowiSekarang dan \#NewEraPrabowoSandi. Sebaliknya, warganet pendukung 01 dikutip dari akun, Adi@rachmatafriadip tweet, pak@jokowimenangthebestlah, \#01IndonesiaMaju \#DebatPintarJokowi \#LebihBaikJokowi, \#Jokowi-OrangBaik, \#JokowiLagi, \#DebatPintarJokowi, \#JokowiMenangLagi, dan \#02GagapUnicorn. Tujuannya untuk menciptakan hubungan cepat antara para pendukung, sehingga tweet warganet antar pendukung akan dengan mudah terorganisir informasinya menjadi menyebar luas (viral).

Analisi sosio-cultural (makro) dalam dimensi praktis sosial-budaya yang ada di luar teks dan konteks dapat mempengaruhi bagaimana wacana dibentuk. Analisis faktor sosial meliputi tiga tingkatan yaitu; situasional, berkaitan dengan kondisi sosial masyarakat yang terbagi anatar 01 dan 02. Menurut (Weber, Garimella, \& Teka 2013), kecenderungan penggunaan tagar pada arena politik (political hashtag trends) ialah untuk mengukur polarisasi dalam masyarakat. Pada arena politik, tagar bekerja dengan dua cara yakni: (i) seed users yakni untuk mengetahui kecenderungan politik, dan (ii) assigned a fractional leaning yakni penandaan kecenderungan faksi-faksi dalam masyarakat. Menurut (Jaffares, 2014) politik tagar adalah pergeseran ke arah penentuan sasaran secara hati-hati dari ide dan kebijakan atau inisiatif khusus yang dilakukan secara instrumental dan konsisten. Karena itu, tagar berfungsi untuk mendapatkan hasil sesuai konteks yang disebarkan kepada masyarakat.

Memproduksi wacana berupa 'kegagalan Pemerintahan, yakni dekonstruksi terhadap citra politik Paslon 01 pada setiap aspek, seperti: nilai tukar rupiah yang merosot terhadap dollar Amerika, daya beli masyarakat yang rendah, pengangguran yang tinggi, kapitalisasi pendidikan, lapangan kerja yang kecil, hutang luar negeri yang meninggi, harga Tarif Dasar Listrik (TDL), Bahan Bakar Minyak (BBM) maupun Sembilan Bahan Pokok (Sembako) yang tinggi maupun persekongkolan pemerintah dengan pihak Asing (Amerika) dan Aseng (Tiongkok). 
Dengan demikian Keduanya ketika konteks debat mengeluarkan sentimen yang beragam sesuai dengan konteks dan perspektif masing-masing, sebagai pembenaran logika. Dari aspek institusional, Paslon 01 memiliki kekuasaan dalam memfungsikan alat kekuasaan, sehingga pembatasan tweet warganet berpengaruh terhadap isi konten. Dari aspek sosial, sejak terkuaknya kampanye negatif yang disertai fakta dan data, ditambah kondisi sosial yang terdegradasi oleh konstruksi makna hoax yang dibangun untuk meruntuhkan demokrasi. Di sisi lain aktor-aktor intelektual politik ikut menghalalkan segala cara untuk tujuan politiknya. Hal ini yang akhirnya menimbulkan situasi keriuhan di antara warganet, sebagai mereka bingung membedakan mana yang benar dan mana yang salah.

\section{Simpulan}

Penyampaian visi misi kandidat Paslon 01 dan Paslon 02 pada "Debat Capres 2019 Putaran Kedua" menuai kontroversi di kalangan pendukung warganet di media sosial khususnya Twitter. Pada akhirnya terjadi perang tagar di ruang virtual. Tagar yang menjadi titik viral yaitu; \#BohongLagiJokowi dan \#02GagapUnicorn. Pada level mikro atau interteks analisis tweet warganet pendukung Capres 02 banyak menggunakan kata ganti objek, frasa, diksi dan penempatan subjek di awal kalimat. Subjek digantikan dengan istilah Mukidi atau Cebong sebagai sosok dagelan atau pelawak yang menyerupai telor katak, juga terdapat penggunaan tagar \#DeleteJokowi atau \#UninstallJokowi sebagai bentuk boikot terhadap Kandidat 01. Sebaliknya, tweet warganet pendukung 01 lebih banyak menggunakan kata diksi, yang merepresentasikan ketidaktahuan Paslon 02 terkait pembahasan Unicorn. Paslon 02 dikontruksi sebagai sosok temperamental, sedangkan Paslon 02 dianggap melakukan kesalahan yang fatal akibat data yang tidak akurat. Relasi komunikasi dari tweet warganet pendukung 01 banyak memunggahan sentimen negatif terhadap kubu lawan dan sebaliknya. Identitas komunikasi dari warganet pendukung 02 menggunakan simbol-simbol komunikasi, \#DeletJokowi, \#Uninstall-Jokowi, \#BohongLagiJokowi, dan \#NewEraPrabowoSandi. Sementara warganet pendukung 01 menggunakan simbol-simbol, \#DebatPintar-Jokowi, \#02GagapUnicorn, dan \#JokowiLagi sebagai integrasi komunikasi virtual. Proses produksi dan reproduksi (messos) terbagi menjadi dua bagian. Antara tweet warganet pendukung 02 dengan akun Sang Kolonel ${ }^{\mathrm{TM}}$ @ cakrabira-wa2000. Tweet warganet 01 melalui akun Adi @ rachmatafriadip menciptakan tren dikalangan pengguna media sosial. Analisis makrostruktur pada tingkat situasional dipengaruhi oleh kondisi sosial politi saat ini. Situasi sosial dilatarbelakangi oleh informasi negatif yang menyerang pada masing-masing kandidat calon, disertai data dan fakta yang ada. Sesuai dengan pembenaran logika masing-masing.

\section{Ucapan Terima Kasih}

Lembaga Penelitian dan Pengabdian Kepada Masyarakat (LPPM) Unsika, Dekan Fisip, Ketua Program Studi Ilmu Komunikasi dan Civitias Akademika Fakultas Ilmu Sosial dan Ilmu Politik Universitas Singaperbangsa Karawang. 


\section{Daftar Pustaka}

Azis. I. (2014). Topik Capres di twitter didominasi kampanye negatif. Retrieved September 14, 2019, from http://sidomi.com/\%0A296222/86 diakses.

Anastasia, \& Emertus. (2014). Efektivitas Twitter Sebagai Medium Promosi. Jurnal UltimaComm, Vol.5 No.1, 1979-1232.

Ayu A. Luthfia. (2019). Cek Fakta: Jokowi Sebut Tak Ada Konflik Pembangunan Selama 4,5 Tahun", (diunggah 16 July 2019) https://nasional.kompas.com/ read/2019/02/17/21362 071/cek-faktajokowi-sebut-tak-ada-konflik-pembangunan-selama-45-tahun?page=all.

Cangara, H. (2009). Komunikasi Politik, Konsep, teori, dan Strategi. Jakarta: Rajawali Pers.

Cangara. H. (2010). Pengantar Ilmu Komunikasi. Jakarta: Rajawali Pers.

Eriyanto. (2001). Analisis wacana, pengantar analisis teks media. Yogyakarta: LKSI.

Fairclough, N. (2013). Critical discourse analysis and critical policy studies. Routledge Taylor \& Francis Group, 7(2), 177-197.

Flew \& Terry. (2002). New Media: An Introduction. New York: Oxford University Press.

Haryatmoko. (2016). Analisis Wacana Kritis: Landasan Teori, Metodologi dan Penerapan. Jakarta: Raja Grafindo Persada.

Haddiyat N. Tamara. (2019). Sentiment on the Presidential Candidate on Twitter: Negative for Jokowi and Prabowo. Retrieved September 13, 2019, from https://katadata.co.id/berita/2019/02/17/sentimen-debat-capres-di-twitternegatif-untuk-jokowi-dan-prabowo

Howarth D. (2010). Power, discourse, and policy: articulating a hegemony approach to critical policy studies, Critical Policy Studies, 3:3-4, 309-335, DOI: $10.1080 / 19460171003619725$.

Kurnia. S. S. (2005). Jurnalisme Kontemporer. Jakarta: Yayasan Obor.

Kusumasari. D., \& Arifianto. S. (2020). Makna Teks Ujaran Kebencian Pada Media Sosial. Jurnal Komunikasi, $12 \quad$ (1), 1-15. http://dx.doi.org/10.24912/jk.v12i1.4045

Nimmo. D. (2004). Komunikasi Politik: Komunikator, Pesan dan Media. Bandung: Rosda Karya.

Piliang. A. A. (2004). "Dunia Yang Dilipat". Yogyakarta: Jalasutra.

Riswandi. (2009). Ilmu Komunikasi (cetakan Pertama). Yogyakarta: Graha Ilmu.

Sahreza. M. (2018). Etika Komunikasi Politik. Retrieved from https://www.researchgate.net/publication/326144065_Ethics_On_Politica 1_Communication

Siagian. H. F. (2015). Pengaruh Dan Efektivitas Penggunaan Media Sosial Sebagai Saluran Komunikasi Politik Dalam Membentuk Opini Publik. Jurnal AlKhitabah, Vol. II, N, 17-26.

Subandi. (2011). Deskripsi kualitatif sebagai satu metode dalam penelitian pertunjukan. Harmonia, 11(2), 173-179. 
Ana Fitriana P, Ema, Fardiah Oktariani Lubis: Perang Tagar Di Ruang Virtual Diskursus Politik Capres Pasca Debat Putaran Kedua

Watie. E. D. S. (2011). Komunikasi dan Media Sosial (Communications and Social $\begin{array}{llll}\text { Media). Jurnal } & \text { The }\end{array}$ https://doi.org/10.26623/themessenger.v3i2.270

Weber, Garimella, V. R., \& Teka, A. (2013). Political tagar trends. (pp. 857-867). Berlin: Springer in P. et al Serdyukov (Ed.), European Confrence on Information Retrieval.

Zarella. G. (2010). The Social Media Marketing Book. Jakarta: Serambi Ilmu. 